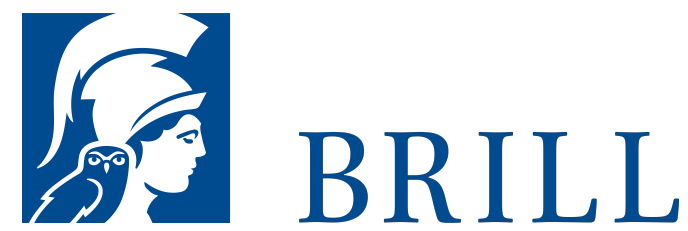

\title{
Logik und Rhetorik der Erkenntnis
}

Zum Verhältnis von wissenschaftlicher und ästhetischer

Weltauffassung. 2. Auflage

Author: Gottfried Gabriel

Logik versus Rhetorik - Das Buch rückt einen Konflikt in den Blick, der das Selbstverständnis des abendländischen Denkens wesentlich mitgeprägt hat. Vor diesem Hintergrund läßt sich die gegenwärtige (an F.Nietzsche orientierte) 'postmoderne' Rückkehr der Rhetorik als ein Aufbegehren gegen logisches Denken in 'scharf begrenzten Begriffen' (G. Frege) begreifen. Mit der rhetorischen Wende geht eine Kritik des Rationalitätsbegriffs einher, in der die anthropologische Frage nach dem angemessenen Verhältnis des Menschen zur Welt im Widerstreit von wissenschaftlicher und ästhetischer Weltauffassung - aufgeworfen wird. In historischsystematischen Untersuchungen zu Themen wie 'Logisches und analogisches Denken', 'Nonsense-Poesie', 'Rätsel', 'Witz und Scharfsinn', 'Fakten und Fiktionen', 'Beispiel und Begriff' wird den Motiven beider Weltauffassungen nachgegangen mit dem Ziel, den Widerstreit aufzuheben und logische und rhetorische Erkenntnisformen als einander ergänzend zur Anerkennung zu bringen.

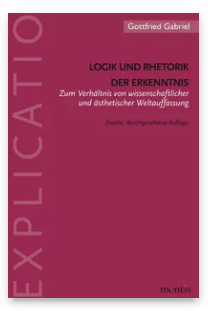

Pages: 150

Seiten

Language:

German

Subjects:

General,

Philosophy

Publisher: Brill | mentis

Series:

Explicatio

E-Book (PDF)

Released online:

15 Dec 2013

ISBN: 978-3-

95743-944-4

List price

Paperback

Publication date:

15 Dec 2013

ISBN: 978-3-

89785-121-4

List price 
For more information see brill.com

Order information: Order online at brill.com +44330 333 0049 | customerservices@brill.com Submission information: brill.com/authors

Titles published by Brill | Fink, Brill | mentis or Brill | Schöningh: +49(o)715413279216| brill@brocom.de 